\title{
ESTABLISHING GOOD GOVERNANCE THROUGH VALUE IMPLEMENTATION OF MONEY PRINCIPLES IN PUBLIC PROCUREMENT POLICY CONTEXT
}

\author{
Vincensya Pingkan Meylinda Palar \\ Diponegoro University \\ vincensyapingkanmp@students.undip.ac.id \\ Kadek Cahya Susila Wibawa \\ Diponegoro University \\ kadekwibawa@lecturer.undip.ac.id \\ Solechan \\ Diponegoro University \\ solechan@lecturer.undip.ac.id
}

\begin{abstract}
This study aimed to review the application of Value for Money principles in public procurement policy to establish good governance in Indonesia. This research used a normative legal method using library research with legal and historical approaches. The results of this study showed that the implementation of Value for Money in public procurement policy is urgent to be applied, which is to encourage the good public procurement practice and produce the right goods/services based on quality, quantity, time, cost, location, and provider aspects; increase the efficiency of the use of public money, which can suppress budget leaks; improve the effectiveness of state financial management; improve the effectiveness and quality of public services; realize a clean government. Arrangements regarding Value for Money in public procurement policy are very clear by the application of e-procurement and utilization of $e$ marketplace; sustainable procurement; and the use of domestic products. This research also indicated the real relevance of the implementation of Value for Money principles in public procurement policy to establish good governance in Indonesia.
\end{abstract}

Keywords; E-Procurement; Good Governance; Procurement Policy; Public Procurement; Value for Money.

\section{A. INTRODUCTION}

Development activities are closely related to public procurement to fulfill the public needs in various forms, like facilities, equipments, and infrastructure, which requires goods and services in the process of achieving them. Development activities are one of the driving factors for the government to carry out public procurement to organize national development ${ }^{1}$.

1 Elvira Uyarra et al., Barriers to Innovation through Public Procurement: A Supplier Perspective, Technovation, 34, no. 10, October, 2014, 631-645, 
The relevance between development activities and public procurement can also be seen from procurement activities that play an important role in development activities, especially to improve public services both in local or regional, also develop the national economy while encouraging its equality ${ }^{2}$. Development activities and public procurement indeed cannot be separated from the use and management of state finances because both of them in their realization are using budgets sourced from the State Budget. Therefore, public procurement requires some arrangements so that the results can be accounted, both physically or financially ${ }^{3}$, and the arrangements are expected to lead to an accountable and transparent government in accordance with the principles of Good Governance.

Government efforts to fulfill the rights and needs of public services are crucial to be accompanied by a strong legal foundation in every public procurement process ${ }^{4}$. Public procurement must ensure legal certainty and protect the public from abuse of authority in the implementation of public procurement to create a conducive climate ${ }^{5}$. In order to improve the accountability of public procurement, the fulfillment process needs to be regulated in a regulation that can guarantee legal certainty and produce quality goods and services ${ }^{6}$.

The regulation of public procurement needs to be regulated by adjusting Indonesia's times and situations. Public procurement has the ultimate goal of ensuring the government to carry out its duties in the implementation of procurement of goods and services in accordance with the principles of public procurement, principles in good governance, and new objectives. It is carried out in public procurement reforms, which is in Presidential Regulation Number 16 of 2018; Value for Money emerged as one of the new goals for public procurement in Indonesia that can be realized by the creation and implementation in policies on public procurement. These principles will later become a unitary aspect that controls and oversees the power held by the government in carrying out its functions in the field of public procurement, especially in any policy of public procurement so that it can run effectively and efficiently.

In public procurement, the government is required to make regulatory improvements, while also open a wider path in increasing the participation of the public and private sectors and combining them with technological advances. To reduce the negative impact of the development of the times for the public procurement, the government initiated 9 (nine)

2 Wenjuan Cheng et al., Green Public Procurement, Missing Concepts and Future Trends - A Critical Review, Journal of Cleaner Production, 176, March, 2018, page.770-784,

3 Hamkah and Hadi Purwanto, Kajian Etika Pengadaan Barang/Jasa Pemerintah, Jurnal Simetrik, 8, no. 2, 2018, page.107-12.

4 Tony Bovaird, Beyond Engagement and Participation: User and Community Coproduction of Public Services, Public Administration Review, 67, no. 5, 2007, page.846-860,

5 Charles Edquist and Jon Mikel Zabala-Iturriagagoitia, Public Procurement for Innovation as Mission-Oriented Innovation Policy, Research Policy, 41, no. 10 (December 2012, page.1757-1769

6 Michael Essig and Alexander Batran, Public-Private Partnership-Development of Long-Term Relationships in Public Procurement in Germany, Journal of Purchasing and Supply Management, 11, no. 5-6, September, 2005, page. 221-231 
forms of public procurement policies/services to achieve Value for Money. In implementing these policies, it is important to understand that the role is not only played by the government but also the public and private sectors, so it can be called good governance.

It is important to understand that "governance" is different from "government". Therefore, to establish good governance, it is necessary to understand the integration of roles between government (bureaucracy), private sector, and the public in rules of play that is mutually agreed ${ }^{7}$ with the ultimate goal of community welfare. ${ }^{8}$ The synergy between the government and non-government in the public procurement policy will facilitate the realization of good governance in Indonesia. Since each party are given the freedom to agree on the content, form, requirements, etc. ${ }^{9}$ of their agreement in order to establish good governance, it must be controlled by the principle of equality, respect for differences in the position and interests of each party and third parties (individuals or communities), and moral values possessed due to human vertical responsibility to the God (honesty, good faith, openness). ${ }^{10}$ The realization of good governance through public procurement policies and its principles will also have an impact on the quality of public services.

As we are well aware, establishing good governance takes a long time and a continuous commitment ${ }^{11}$. Therefore, the three main pillars in government (the government, society, and the private sector) need to work together to achieve it. It must be considered that the main key in understanding good governance is the understanding of the principles in it. ${ }^{12}$

Public procurement is expected to run in a better direction, in which all parties need to understand the reform of public procurement regulation in Presidential Regulation No. 16 of 2018 by looking at the implementation of Value for Money principles in every government procurement policy. They also need to look for the urgency of implementation Value for Money in public procurement policy and its relevance in order to establish good governance in Indonesia through the analysis and understanding of Presidential Regulation Number 16 of 2018 as the main guideline in implementing the public procurement. This aims to establish good

7 Shafiera Amalia, "Reformasi Birokrasi 4.0: Strategi Menghadapi Revolusi Industri 4.0," Jurnal Wacana Kinerja: Kajian Praktis-Akademis Kinerja Dan Administrasi Pelayanan Publik 21, no. 2 (2018): 1-18,

8 Beridiansyah Beridiansyah, Analisis Yuridis Terhadap Pengadaan Barang Dan Jasa Guna Mencegah Tindak Pidana Korupsi, Integritas 3, no. 2, 2017, page.79,

9 Richo Andi Wibowo, "Embodiment Concept of Good Governance as Principles in Public Procurement," UNISIA 37, no. 76, 2012, page.28-40.

10 Kadek Cahya Susila Wibawa and Ajik Sujoko, The Concept of Private-Administration Contracts in Settling Problems in Government Goods / Services Procurement Contracts, 2021, page.662-667.

11 Putra Astomo, Penerapan Prinsip-Prinsip Pemerintahan Yang Baik Dalam Penyelenggaraan Pemerintahan, Kanun: Jurnal IImu Hukum 16, no. 3, 2014, page.401-20

12 Kadek Cahya Susila Wibawa, Urgensi Keterbukaan Informasi Dalam Pelayanan Publik Sebagai Upaya Mewujudkan Tata Kelola Pemerintahan Yang Baik, Administrative Law \& Governance Journa/2, no. 2, 2019, page.218-234. 
governance that has been incorporated in various laws and regulations in Indonesia.

Based on this description, this research focuses on the application of the principle of value for money in the policy of procurement of goods and services in Indonesia. Novelty in this article is to find a meeting point (balance) between the principle of value for money and the principle of legality in the policy of procurement of goods and services as an effort to realize good governance in Indonesia. The purpose of this study is to describe the urgency of applying the principle of value for money in procurement policies and to describe the correlation of the principle of value for money and the implementation of good governance in government procurement activities.

\section{B. RESEARCH METHODS}

This study was normative research with a legal approach. The legal approach was used to examine the laws and regulations related to the legal issue of this study, which in this case are policies that are related to public procurement and the implementation of Value for Money principles in every public procurement policy in order to establish good governance in Indonesia $^{13}$. The technique of data collection for this research was library research to find any theories, Ius constitutum, and experts' viewpoints that might support and strengthen the author's analysis. In addition, data was also collected from interviews with procurement practitioners ${ }^{14}$.

Those collected data went through an interpretation process performed by the author to be deeply analyzed by studying and reviewing the regulation of Value for Money principles incorporated in each public procurement policy in Presidential Regulation Number 16 of 2018. Those data were cross-checked to find the urgency of implementation of Value for Money in public procurement policy and its relevance in order to establish good governance in Indonesia. Therefore, data analysis was done qualitatively.

\section{RESULT AND DISCUSSION}

\section{Urgency of Value for Money in public procurement policy}

PBJP regulatory reforms are performed through Presidential Regulation No. 16 of 2018 with the concept of Value for Money. The former PBJP concept required procurement to find the lowest price and consider the quality. Value for Money leads PBJP to a better direction, which is by focusing on prices with quality possessed so that with this change in value, PBJP must (1) adopt market mechanism that are open, prices that reflect quality, and provide many choices/variants; (2) adopt

13 Aga Natalis, Urgensi Kebijakan Penyelenggaraan Anggaran Pendapatan dan Belanja Daerah dalam Mewujudkan Kesejahteraan Perempuan, Pandecta Research Law Journal 15, no. 1 June 15, 2020, page.64-73

14 Depri Liber Sonata, Metode Penelitian Hukum Normatif Dan Empiris: Karakteristik Khas Dari Metode Meneliti Hukum, FIAT JUSTISIA: Jurnal IImu Hukum 8, no. 1, November 5, 2015, page.15-35, 
a series of world-recognized best practices and established business practices.

Even though the concept of Value for Money is not mentioned directly in Presidential Regulation No. 16 of 2018, according to this concept, the right procurement of goods/services can be measured from every money spent and the appropriateness of various aspects mentioned in Article 4 letter a of the Presidential Regulation No. 16 of 2018, including aspects of quality, quantity, time, cost, location, and provider. In this article, it is clearly that Value for Money becomes part of the objective of implementing the PBJP. This principle is a crucial aspect to apply in implementing PBJP since Value for Money does not only about a tool or method but a way of thinking in using existing resources and funds to obtain the desired objectives by employing the balance among the three main elements including economical, efficient, and effective. It is expected that the application of Value for Money in the PBJP policy will produce the right goods/services for every money spent as measured from various aspects.

To achieve the goals of procurement, a procurement policy is required as a government strategy to achieve Value for Money and other PBJP goals by applying and guided by the PBJP principles. Overall, there are six principles including efficient, effective, transparent, open, competitive, fair, and accountable. These six principles are utilized as guidelines for thinking or acting in implementing policies for procurement of goods/services so that in alternatively stated, the application of these principles is the same as a fundamental statement or truth in general or in particular, and it can be divined that the goods/services obtained will be suitable. The specifications, maximum quality, and minimum cost of procurement, as well as seen from the perspective of the goods/services provider, a healthy competition will be established and in turn, will encourage the increasing quality and ability of the goods/service providers. An effective and efficient value as the principle of PBJP is also part of the element of Value for Money.

Value for money has been regulated and implemented in procurement policies, such as in e-procurement. E-procurement is believed by the government as a tool or appliance to realize good governance, clean governance, good corporate governance, and public services. E-procurement is a procurement that is done by a buyer organization to a provider electronically. It is carried out for the primary reason of improving the effectiveness and efficiency of public services, which is also the government's obligation as a public servant. It improves the use of information communication technology and electronic transactions and transparency, accountability, market access, and fair business competition ${ }^{15}$.

15 Kodar Udoyono, E-Procurement Dalam Pengadaan Barang Dan Jasa Untuk Mewujudkan Akuntabilitas Di Kota Yogyakarta, Journal of Government and Politics 3, no. 1, February 1, 2012, page. 127-160 
The government's new policy in the PBJP sector associated with the utilization of technology and electronics was realized through its new program of the Procurement Defense Program. This program aims to support the MSEs Go Digital Program through the process of direct shopping K/L/PD with a maximum value of IDR 50,000,000.00 (fifty million rupiahs) to MSEs that are members of the Marketplace. ${ }^{16}$ Besides functioning to encourage MSEs to Go Digital by joining marketplaces like Blibli.com, Shopee, Grab, Gojek, etc., the Procurement Defense Program which in its implementation prioritizes the utilization of technology and electronic transactions, it also functions to make procurement more inclusive, improving the use of domestic production, utilizing the marketplace in PBJP, and increasing PBJP transparency and accountability. The five functions of the Procurement Defense Program becomes a part of the government's efforts to achieve Value for Money by establishing technology and the application of electronic transactions in the procurement of goods/services. These functions aim to make the transactions more effective, efficient, and economical to achieve Value for Money and good governance with public and private participation in each procurement process.

Given that the value of the rupiah in the APBN and APBD nowadays is different from ten years ago and the difference in needs between the past and the present is highly complex, therefore, these have an impact on government procurement of goods and services. Hence, the application of Value for Money becomes urgent so that every fund that is spent can be following the aspects that have been determined. The government is trying to implement a policy in the PBJP to emphasize that Value for Money is crucial in PBJP activities, such as by improving the quality of procurement planning ${ }^{17}$, as contained in Article 18 paragraph (1) of Presidential Regulation No. 16 of $2018 .^{18}$ The consistent and sustainable improvement and implementation of PBJP policies and the utilization of information technology will be able to encourage the realization of PBJP that generates Value for Money.

The above discussion indicates some of the urgency of implementing the principle of Value for Money (by balancing the three main elements of Value for Money) for government procurement policies, including encouraging good government procurement practices ${ }^{19}$. The practice of procuring good goods/services is also described by Christian Gamas, in which procurement is done by applying international best practices that have been adapted to existing conditions in Indonesia.

16 Decree of the Head of the Government Goods / Services Procurement Policy Institute Number 200 of 2020 concerning the Procurement Defense Program

17 Procurement planning includes identification of needs, determination of goods/services, methods, schedules, and budget for the procurement of goods/services.

18 Christian Gamas, S.T.,M.M.,AFP.,CP.NLP., Wawancara, Fasilitator Pengadaan Barang/Jasa Pemerintah Nasional tingkat Dasar LKPP RI, (Kutai Barat: 13 Januari 2021)

19 Dwi Purwiyanti, Analisis Kinerja Berbasis Konsep Value for Money Pada Kegiatan Fisik Pekerjaan Irigasi Donggala Kodi (study Di Dinas Pekerjaan Umum Kota Palu), e Jurnal Katalogis 5, no. 3, 2017, page.190-200. 
Therefore, good procurement of goods/services means an implementation of Presidential Regulation No. 16 of 2018 as optimal as possible not as finest as possible. Implementing PBJP regulations optimally means that the procurement of goods/services runs following the context of the procurement of goods/services, meeting all needs but with due regard to the primary points that the procurement is carried out without violating existing rules and not neglecting objectives, policies, principles, and ethics in PBJP. According to him, good procurement also not only meets the PBJP objectives in Article 4 letter a (Value for Money) but also meets as many PBJP objectives as possible as stated in Article 4 of the Presidential Regulation No. 16 of $2018 .{ }^{20}$

Through the implementation of Value for Money, the application of the elements of efficiency, effectiveness, and economy in each PBJP policy and each stage of its procurement, particularly the identification of needs, is deemed as the first step in implementing Value for Money in PBJP. This is carried out to create service and goods of the government that meet the principles of quality, quantity, time, cost, location, and provider.

The implementation of the Value for Money principle can also improve the efficiency of the use of state finances, which can minimize budget leakage. Article 3 of Act No. 17 of 2003 also describes that the use of state finances needs to be managed with the effective and efficient principles. To streamline the use of state finances indicates that every state finance spent on the procurement of government goods and services can achieve particular benefits as much as possible.

PBJP is part of the management of state finances. Therefore, by making arrangements in the PBJP sector and implementing the principle of Value for Money in every PBJP policy, effectiveness in the management of state finances is also maintained. Effectiveness in the PBJP policy indicates the suitability of the goods and services produced following the original purpose for which the procurement was done, as well as in accordance with the identification of needs, as much as possible to strive for the welfare of the community. Besides, the implementation of the Value for Money principle can also establish clean governance and improve the effectiveness and quality of public services.

Improving the quality of public services becomes part of the objectives of regulating the procurement of government goods/services. Value for Money with its three elements strives to create the right and suitable goods in all aspects. The accuracy of procurement seen from all aspects will also give its effect on public services. The concept of Value for Money is not only about saving budget, but it concerns public services, which focuses more on the results of work that have value whose advantages can essentially be enjoyed by the community and are relevant both for the present and the future. Alternatively stated, the

20 Christian Gamas, S.T.,M.M.,AFP.,CP.NLP., Wawancara, Fasilitator Pengadaan Barang/Jasa Pemerintah Nasional tingkat Dasar LKPP RI, (Kutai Barat: 13 Januari 2021) 
budget issued to the maximum extent possible has an optimal impact for all parties, particularly for improving the quality of public services.

Till date, apart from the limited ability to translate the procurement requirements that must be purchased rigidly and in detail, the primary barrier to the implementation of value for money in PBJP policy is the wrong mindset concerning the fear of performing procurement at higher costs. It must be considered that the price aspect is not the priority in measuring Value for Money in a PBJP, but the quality aspect, followed by the quantity aspect, followed by the time aspect which ranks third, the cost as the fourth priority, and followed by location and provider as the fifth and sixth priorities. Therefore, it makes Value for Money significant to be applied with the primary priority of the aspects of the quality of goods/services above the aspect of cost. ${ }^{21}$

\section{Relevance of the implementation of value for money principles in public procurement policy to establish good governance}

Recognizing that the effort to realize good governance needs a long period and continuous commitment ${ }^{22}$, the three major pillars in government/governance, society, and the private sector need to collaborate to achieve it, considering the main key in understanding good governance is understanding the principles therein. ${ }^{23}$ Therefore, good governance can be interpreted as the practice of democratic governance and the ability to manage the social and economic interests of the Indonesian people properly according to the principles of deliberation and consensus. Meanwhile, its form in Indonesia is of clean, efficient, effective, responsive, and responsible governance, responsible, acting, and taking sides in the interests of the community, in the life order of Indonesian society based on Pancasila. The interaction between government and non-government develops trust between the government and non-governmental elements indirectly as the primary element in supporting good governance practices in Indonesia. ${ }^{24}$ The government in PBJP functions as a regulator which is only to regulate. The synergy between the government, the private sector, and the community that is expected to achieve good governance through PBJP need to begin with good integrity of each element. The first step is to consider the quality of procurement planning (identification of needs in

21 Christian Gamas, S.T.,M.M.,AFP.,CP.NLP., Wawancara, Fasilitator Pengadaan Barang/Jasa Pemerintah Nasional tingkat Dasar LKPP RI, (Kutai Barat: 13 Januari 2021)

22 Astomo, Putra, Penerapan Prinsip-Prinsip Pemerintahan Yang Baik Dalam Penyelenggaraan Pemerintahan, Kanun: Jurnal Ilmu Hukum 16, no. 3, 2014, page. 401-420

23 Wibawa, Kadek Cahya Susila, Urgensi Keterbukaan Informasi Dalam Pelayanan Publik Sebagai Upaya Mewujudkan Tata Kelola Pemerintahan Yang Baik, Administrative Law \& Governance Journal, 2, no. 22019 page.218-34

24 Achmad Hidayat Rahadian, Mewujudkan Good Goverment, Jurnal Ilmiah Sekolah Tinggi IImu Administrasi MAndala Indonesia (STIAMI) 1, no. 2, 2009, page.57-70. 
detail, determination of goods/services also needs harmonization between each community). ${ }^{25}$

The synergy between government and non-government in goods and service procurement policies of the government will facilitate the realization of good governance in Indonesia so that this realization will also affect the quality of public services which will be felt by the public and the private sector directly. ${ }^{26}$

For instance, the use of e-procurement will make it easier and faster for the government to procure goods/services. As an illustration, using an e-marketplace to procure goods/services will meet the principle of efficiency because in this case, procurement is done by optimizing each resource both in the procurement process and the supply of goods/services required. Besides, electronic PBJ will provide convenience in the monitoring and audit process and meet the need for real-time access to information to realize good corporate governance in the procurement of goods/services provided by the government. ${ }^{27}$ The government is the party that requires goods/services and has the authority to use the APBN to procure goods/services.

On the other hand, if non-governmental parties are linked to good governance, the public can easily access any data on the procurement of goods/services done by the government. PBJP cannot be separated from government spending so that the community is necessary to actively participate in monitoring the government in utilizing and managing state finances with economic, effective, and efficient benchmarks following the Value for Money principles. Meanwhile, the role of the private sector is also required in implementing PBJP policies and processes according to the principles of effectiveness and efficiency. It is performed to achieve Value for Money and to realize good governance. The private sector, in its role as a provider of PBJP, needs to utilize information technology and electronic transactions to offer the goods/services they possess or commonly referred to as private goods to be allocated into public goods. The effectiveness and efficiency of the utilization of electronic systems, in this case, can be observed in the role of the private sector which will play a crucial impact, which is in addition to healthy competition among PBJP providers, e-procurement will also make it easier for the government in the supplier selection stage.

The relevance of the Value for Money principle in the PBJP policy in realizing good governance in Indonesia can be observed from several aspects. At least three reasons reinforce that there is a real relevance of the implementation of Value for Money principles in PBJP policies to realize good governance in Indonesia: (1) from the aspect of objectives, it shows that the objectives of good governance and PBJP are the same,

25 Christian Gamas, S.T.,M.M.,AFP.,CP.NLP., Wawancara, Fasilitator Pengadaan Barang/Jasa Pemerintah Nasional tingkat Dasar LKPP RI, (Kutai Barat: 13 Januari 2021)

26 Andi Hakim, Dinamika Pelaksanaan Good Governance Di Indonesia (dalam Perspektif Yuridis Dan Implementasi), Civil Service 10, no. 1, 2016, page.15-33.

27 Lembaga Kebijakan Pengadaan Barang/ Jasa Pemerintah, Modul Pelatihan PBJP Berbasis PERPRES No.16 Tahun 2018, ed. Kementrian Pendidikan dan Kebudayaan, Jakarta, 2018 
which is to seek the welfare of the community as large as possible. (2) Community welfare as the primary goal, in the concept of good governance, needs to be achieved jointly by the government and nongovernment. When related to the implementation of Value for Money, the welfare of the community needs to be realized collectively, in accordance with balancing economic, effective, and efficient elements. The two major elements in Value for Money are also the principles that are used as guidelines for thinking or acting in implementing goods/services procurement policies, which are effective and efficient.

A crucial point for interpreting the relevance of the implementation of Value for Money in PBJP policies to achieve good governance is by improving the utilization of information communication technology and electronic transactions. Electronic PBJP or better known as e-procurement is carried out by a buyer organization with a provider electronically. Electronic procurement transactions can be performed between business organizations and other businesses, business organizations with consumers, or government organizations with businesses as providers. E-procurement can be seen from the procurement of goods/services of the government that use emarketplaces (e-purchasing, e-tendering, online shops), e-catalogs, and other types of electronic systems utilized in the procurement of government goods and services. It is performed for the primary reason of increasing the effectiveness and efficiency of public services, which also becomes the government's obligation as a public servant. It improves the utilization of information communication technology and electronic transactions, transparency, accountability, market access, and fair business competition.

An example of the implementation of efficiency and effectiveness by the government is manifested in the action of the President of the Republic of Indonesia in issuing a special Presidential Instruction Number 1 of 2015 to encourage the acceleration of absorption of the state finances through state expenditure, particularly with the implementation of PBJP. This policy is an instruction to all heads of Ministries/Institutions/Central and regional regions to take strategic steps promptly in the context of accelerating PBJP through e-procurement and e-purchasing systems according to e-catalogs. The utilization of eprocurement will make it easier and faster for the government to procure goods/services, for instance by using an e-marketplace to procure goods/services, meets the principle of efficiency because in this case, procurement is performed by optimizing each resource, both in the procurement process and providing the required goods/services. Besides, electronic PBJ will provide convenience in the monitoring and audit process and fulfill the need for real-time access to information to achieve good corporate governance in the procurement of goods/services by the government. ${ }^{28}$

28 Ibid. 
Meanwhile, the role of the private sector is also required in implementing PBJP policies and processes according to the principles of effectiveness and efficiency. It is carried out to achieve Value for Money and realize good governance. The private sector, in its role as a provider of PBJP, requires using information technology and electronic transactions to offer the goods/services they possess or commonly referred to as private goods to be allocated into public goods. The effectiveness and efficiency of utilizing electronic systems, in this case, can be observed in the role of the private sector which will give a significant impact, which is in addition to healthy competition among PBJP providers, e-procurement will also facilitate the government in the stage of selecting providers. (3) PBJP is part of the implementation of public services; on the other hand, good governance can also be achieved through public services. Public services in Indonesia have tended to "run in place", and do not represent the timeliness and costs needed and used, while, in terms of implications, public services are too broad in economic, political, social, and cultural life. ${ }^{29}$ The government as a public servant must fulfill the needs of the community. Returning to the concept of government procurement of goods/services, it can fulfill the needs of the community by procuring goods/services within the scope of the government. As the state administrator, the government tries to fulfill the aspects that are of necessity to the community with all PBJP processes according to the management of state finances to realize economics, effectiveness, and efficiency in the utilization of state finances. Meanwhile, in the context of this public service, nongovernment not only enjoy these public services but also has a significant role in monitoring the government, in which case the government has the authority to manage state finances through the procurement of government goods/services.

The initial step of the government in providing public services is through PBJP, on the other hand, public services are the primary driving force to realize good governance because that is the role of the government as public servants and non-government is seen as supervisors of these public services so that the government is not arbitrary in performing its obligations, particularly in the procurement of goods/services by the government.

\section{CONCLUSION}

Based on the discussion, We conclude that at least there are five urgencies of implementation the principle of Value for Money (by balancing the three main elements of effective, efficient, and economical) for public procurement policy are: encouraging the practice of good public procurement, and producing the proper goods/services quality, quantity, time, cost, location, provider; improve the efficiency of the use of state finances, which can suppress budget leaks; improve the effectiveness of

29 Rahadian, Mewujudkan Good Goverment, Jurnal Ilmiah Sekolah Tinggi Ilmu Administrasi MAndala Indonesia (STIAMI), 1, no. 2, 2009, page.57-70 
state financial management; improve the effectiveness and quality of public services; and establish a clean government. The relevance of the implementation of Value for Money principles in public procurement policy to establish good governance in Indonesia are: First, the similarity of goals and principles between good governance and public procurement, which aims at the welfare of the community, and has a principle that is similar with Value for Money's elements that is effective and efficient. Second, the welfare needs to be achieved together among three important parties in good governance (government, public, and private sectors), with balancing the Value for Money elements. Third, public procurement is part of the implementation of public services, on the other hand, good governance can also be achieved through public services, and so by implementing value for money in public procurement policy indirectly, it is the same as establishing good governance in Indonesia.

Journals :

\section{BIBLIOGRAPHY}

Amalia, Shafiera, Reformasi Birokrasi 4.0: Strategi Menghadapi Revolusi Industri 4.0. Jurnal Wacana Kinerja: Kajian Praktis-Akademis Kinerja Dan Administrasi Pelayanan Publik 21, no. 2, 2018;

Astomo, Putra, Penerapan Prinsip-Prinsip Pemerintahan Yang Baik Dalam Penyelenggaraan Pemerintahan. Kanun: Jurnal IImu Hukum 16, no. 3, 2014;

Beridiansyah, Beridiansyah, Analisis Yuridis Terhadap Pengadaan Barang Dan Jasa Guna Mencegah Tindak Pidana Korupsi, Integritas 3, no. 2, 2017;

Bovaird, Tony, Beyond Engagement and Participation: User and Community Coproduction of Public Services. Public Administration Review 67, no. 5, 2007;

Cheng, Wenjuan, Andrea Appolloni, Alessio D'Amato, and Qinghua Zhu, Green Public Procurement, Missing Concepts and Future Trends - A Critical Review. Journal of Cleaner Production 176, March, 2018;

Edquist, Charles, and Jon Mikel Zabala-Iturriagagoitia, Public Procurement for Innovation as Mission-Oriented Innovation Policy. Research Policy 41, no. 10, December, 2012;

Essig, Michael, and Alexander Batran, Public-Private Partnership-Development of Long-Term Relationships in Public Procurement in Germany, Journal of Purchasing and Supply Management 11, no. 5-6 September, 2005;

Hakim, Andi, Dinamika Pelaksanaan Good Governance Di Indonesia (dalam Perspektif Yuridis Dan Implementasi), Civil Service 10, no. 1, 2016; 
Hamkah, and Hadi Purwanto, Kajian Etika Pengadaan Barang/Jasa Pemerintah, Jurnal Simetrik 8, no. 2, 2018;

Juliani, Henny, Akibat Hukum Penyalahgunaan Wewenang Administrasi Pejabat Pemerintahan Yang Menimbulkan Kerugian Keuangan Negara, 2, no. 4, 2019;

Lembaga Kebijakan Pengadaan Barang/ Jasa Pemerintah, Modul Pelatihan PBJP Berbasis PERPRES No.16 Tahun 2018. Edited by Kementrian Pendidikan dan Kebudayaan. Jakarta: LKPP, 2018.

Natalis, Aga, Urgensi Kebijakan Penyelenggaraan Anggaran Pendapatan dan Belanja Daerah dalam Mewujudkan Kesejahteraan Perempuan., Pandecta Research Law Journal 15, no. 1, June, 2020;

Purwiyanti, Dwi, Analisis Kinerja Berbasis Konsep Value for Money Pada Kegiatan Fisik Pekerjaan Irigasi Donggala Kodi (study Di Dinas Pekerjaan Umum Kota Palu, e Jurnal Katalogis 5, no. 3, 2017;

Rahadian, Achmad Hidayat, Mewujudkan Good Goverment. Jurnal IImiah Sekolah Tinggi IImu Administrasi MAndala Indonesia (STIAMI) 1, no. 2, 2009;

Sonata, Depri Liber. Metode Penelitian Hukum Normatif Dan Empiris: Karakteristik Khas Dari Metode Meneliti Hukum, FIAT JUSTISIA: Jurnal IImu Hukum 8, no. 1, November 5, 2015;

Udoyono, Kodar, E-Procurement Dalam Pengadaan Barang Dan Jasa Untuk Mewujudkan Akuntabilitas Di Kota Yogyakarta, Journal of Government and Politics 3, no. 1, February 1, 2012;

Uyarra, Elvira, Jakob Edler, Javier Garcia-Estevez, Luke Georghiou, and Jillian Yeow, Barriers to Innovation through Public Procurement: A Supplier Perspective, Technovation 34, no. 10, October 2014;

Wibawa, Kadek Cahya Susila, Urgensi Keterbukaan Informasi Dalam Pelayanan Publik Sebagai Upaya Mewujudkan Tata Kelola Pemerintahan Yang Baik, Administrative Law \& Governance Journal 2, no. 2 2019;

Wibawa, Kadek Cahya Susila, and Ajik Sujoko, The Concept of PrivateAdministration Contracts in Settling Problems in Government Goods / Services Procurement Contracts, 2021,;

Wibowo, Richo Andi, Embodiment Concept of Good Governance as Principles in Public Procurement, UNISIA 37, no. 76, 2012; 